\title{
Obamovo tělo
}

\section{Performativní aspekty politické rétoriky ${ }^{1}$}

\author{
Matthias Warstat \\ Překlad Marie Kunderová a Radka Kunderová
}

Už před svým nástupem do funkce 44. prezidenta Spojených států 20. ledna 2009 se Barack Obama stal ikonou současné politické tělesnosti. Komentátoři po celém světě byli nadšeni nejen jeho mnohoslibnými politickými idejemi a nadějí na nový obrat ve Washingtonu, ale i nekonvenčním způsobem, jakým Obama svi̊j reformní program ztělesňoval na veřejnosti. Od té doby se ještě utvrdil dojem, že v Obamově sebeprezentaci politika a tělo zvláštně spolupůsobí. Daleko více než jeho předchůdce George W. Bush, ale jinak než fyzicky stejně silně prézentní Bill Clinton, umí Obama uplatnit své tělo v politické komunikaci. Dalo by se snad dokonce říct, že našel aktuální koncept tělesné prezentace v politice. Jak se dá tento koncept analyzovat? Co reprezentuje Obamovo tělo ve spletitých veřejných debatách o moci, vedoucí úloze prezidenta a demokratické legitimitě? Jaké perspektivy budoucí podoby politické veřejnosti se odvíjejí od způsobu, jakým je Obamovo tělo celosvětově prezentováno médii? Tyto otázky budou dále rozebrány z teatrologického pohledu, aniž by směřovaly ke konkrétním doporučením, jak dosáhnout úspěšné prezentace řídících schopností. $\mathrm{V}$ tomto ohledu je na místě zdrženlivost, protože Obamův případ v neposlední řadě ukazuje, jak tě̌̌ké je úspěšné individuální strategie sebeprezentace přenášet médii, natož pak napodobit. Ojedinělé pokusy německých politiků přisvojit si jednotlivá Obamova gesta nebo slogany žalostně selhaly. Sebeprezentační strategie proto nemohou být jednoduše přebírány, protože jsou vázány na fyziognomii konkrétních těl, která není možné neomezeně transformovat. Tyto tělesné komponenty politické performance budou dále podrobněji analyzovány na Obamově př́kladu.

Od vydání vlivné studie Ernsta Kantorowicze The King‘s Two Bodies (1957)² je otázka významu těla pro vznik moderní státnosti jedním z klasických témat politické teorie. ${ }^{3}$ Ve vztahu ke králům křest̉anského středověku poukázal Kantorowicz na zásadní rozlišování mezi přirozeným, smrtelným a nadpřirozeným, nesmrtelným tělem vládce. Toto pojetí dvojího těla bylo rozhodujícím krokem na cestě k evropské ideji novodobého státu. Představa o trvalosti a nedotknutelnosti státních institucí spočívala v přesvědčení, že vládnutí nesmí být výhradně svázáno s chybujícím, pomíjivým a zranitelným

\footnotetext{
1 Studie vyšla pod názvem „Obamas Körper. Performative Aspekte politischer Rhetorik“ (WARSTAT in WEIBLER 2010: 173-189). Pozn. red.: Citační norma studie byla upravena podle citační normy Theatralii.

2 Pozn. překladatelek: v češtině vyšlo pod názvem Duě těla krále. Praha: Argo, 2014. ISBN 978-80-257-1240-5.

3 V němčině vyšlo v roce 1992 (KANTOROWICZ 1992).
} 
biologickým tělem člověka. Už přívrženci středověkého království věděli, že vedle tohoto živoucího těla (Leib) je potřebná ještě tělesnost abstraktní, schopná překonat ohraničený čas daný fyzickému tělu. Funkce takové tělesnosti postupně přebíraly další a další instituce novodobé státnosti.

Ve stř̌edověku však spočívala idea nesmrtelnosti ještě bezprostředně v těle krále. Vážnost královského úřadu vyvrcholila v konvergenci dvou těl, která se jako tělesná realita i jako institucionální moc protínala v jedné a téže osobě. Poté, co byla abstraktní královská hodnost $\mathrm{v}$ procesu formování moderní státnosti vystřídána mocnými institucemi, se změnily předpoklady pro tázání ohledně významu vládcova těla. Přestože bylo jeho tělo od tohoto okamžiku připraveno o svou nesmrtelnost, zdálo se být i nadále obklopeno zvláštní aurou, která se pouze musela začít vysvětlovat jinými slovy. Za pokus pojmově uchopit sílu přitažlivosti těla moderního politika můžeme považovat pojem „charisma“" Maxe Webera, rozvinutý v díle Wirtschaft und Gesellschaft (1922). ${ }^{4}$

Tělesností politiků se však nezabývají jen sociální teorie, kulturní sociologie a politická filozofie. Také divadelní vědě, která se zabývá formami znázornění politična, se vyplatí objasnit, jak a za jakým účelem se objevuje tělo v politické sféře. Pokud je řeč o „ělesném zjevu“ (leiblichen Erscheinen), nenahlíží se na tělo (Körper) jako na pouhé médium, které v procesu zprostředkování zprávy dříve nebo později zmizí. ${ }^{5}$ Naopak se zdůrazňuje svébytnost těla v politickém střetávání: tělo má svou vlastní realitu v politické veřejnosti (politische Öffentlichkeit), nedá se odmyslet od interakcí mezi vládnoucími a ovládanými, držiteli moci a voliči, aktéry a diváky. Na jedné straně politická filozofie foucaultovského ražení tělo silně redukovala na pasivní veličinu: pod pojem biopouvoir (bio-moc) shrnuje Foucault všechny soudobé politické strategie, jimiž moderní stát utváří těla svých poddaných (od dietních předpisů přes hygienická nařízení, posilovací programy, zdravotnická zařízení až po kontrolu porodnosti). ${ }^{6} \mathrm{Na}$ druhé straně je ale třeba tělo analyzovat i jako aktivní součást politických vztahů. $\mathrm{V}$ politické performanci, tj. ve viditelném veřejném počínání politiků, může být tělo rozhodující veličinou. $V$ tom spočívá špatná zpráva pro ty, kteří věří, že se kvality politického vủdce dají osvojit učením. Dnes samozřejmě patř́i nastudování nejdůležitějších sebeprezentačních triků, jak zapůsobit na publikum, $\mathrm{k}$ výbavě každého profesionálního politika. Ale tělo se svou fyziognomií, vzhledem a svou vlastní vahou vzpírá úplnému strategickému modelování. Zůstává v politické každodennosti nepolapitelné, neuchopitelné, a proto má pro úspěch politické komunikace zásadní význam.

Kulturologické a uměnovědní obory se v posledních letech při teoretickém zkoumání těla vydaly dvěma protikladnými cestami. V návaznosti na teorie dekonstrukce, a zvláště na performanční teorii Judith Butlerové bylo zkoumáno diskursivní vytváření těl. Pojetí této školy by se dalo shrnout následovně: těla se svými zvláštnostmi a vlastnostmi tu nejsou jednoduše $\mathrm{k}$ dispozici, ale teprve se konstituují prostřednictvím jazyka

4 K aktuální formulaci charizmatického potenciálu politiků (HITZLER in SOEFFNER a TÄNZLER 2002: 35-49).

5 K rozlišení pojmů Leib a Körper (BARKHAUS a FLEIG 2002: 9-23).

$6 \quad$ Poprvé rozvinul tento pojem ve (FOUCALT 1997). 
a přisuzováním jejich významu v každodenním počínání. „Doing gender“ (vytvářeni genderu), tato formulace Judith Butlerové přesně vystihuje myšlenku diskursivního konstituování těl: žádný člověk se nenarodí jako muž nebo žena, jako chlapec nebo děvče. K tomu, že určité části těla pokládáme za primární nebo sekundární pohlavní znaky, vedou historicky ustavená pravidla mluvení a jednání. Ne biologické skutečnosti, ale společenské konvence rozhodují o tom, že jsou určité způsoby chování vnímány jako „ženské“ nebo „mužské“. Taková dichotomická přiřazení pramení podle Butlerové z heterosexuálního nátlakového systému, který je třeba překonat. Ale také odhlédneme-li od feministických politických požadavků, je teorie kulturního konstruování těla vhodná $\mathrm{k}$ analýze veřejné prezentace těl (politiků). Protože to, co bylo ukázáno na př́kladu pohlavních atributů, platí také pro nejrůznější další charakteristické znaky připisované tělu: kdo chce pochopit, jak jsou vnímána těla a jak působí, ten se musí zabývat významy, které jsou jim přisuzovány. Spojitosti mezi tělem a významem jsou stanoveny společenskými diskursy, jejichž funkčnost v konkrétních historických kontextech je možné kulturologicky analyzovat.

Jiný směr kulturního a uměnovědného studia tělesnosti se k tezi, že se těla vytvářejí teprve při mluvení nebo jednání, staví kriticky. Krédem této fenomenologicky inspirované opozice je, že bez těla neexistuje ani vnímání, ani subjektivita, ani Já, které by mohlo přisuzovat něčemu význam. Potud by muselo být tělo nejprve chápáno jako něco daného (a ne jako konečný bod procesu konstruování). ${ }^{8}$ Fenomenologické teorie těla se pokoušejí rozvíjet chápání a řeč jako danosti těla. Vycházejíce z tohoto záměru dospívají i k metodologicky zcela odlišnému zacházení s tělem. Místo studia jazykových výkladů a okupování těla doporučují fenomenologové usilovat o vhled do těla. Je opravdu rozdíl v tom, jestli se analyzují projekce zaměřené na povrch těla, nebo se tělo zkouší procítit takřka „zevnitř̌“. Tímto zpo̊sobem sice nezískáme přesný obraz našich vnitřních orgánů a struktur, ale můžeme se pokusit vědoměji vnímat tento amorfní, pohyblivý a dynamický vnitřní svět. Podobně se můžeme zaměřit na to, jak popsat z pozice vnímatele vyzařování jiného těla, se kterým se setkáme. Němčina nabízí pro toto jiné zacházení s tělem dokonce alternativní pojem: filozofové jako Hermann Schmitz, Gernot Böhme nebo Bernhard Waldenfels mluví o „těle“ (Leib), aby popsali tělo (Körper) jako něco daného, pocitovaného, jako o „přírodě, kterou jsme my sami“ (BÖHME 2008: 119-135).

Na Baracku Obamovi se dá exemplárně ukázat, jak mnohovrstevná je relevance tělesna v inscenacích politiky. Přestože se Obama právě v době volebního boje v roce 2009 těšil velmi nadprůměrné popularitě, už tehdy jeho tělo podněcovalo protichůdná stanoviska a kontroverzní debaty. Zdá se výhodné naznačit propojení mezi způsobem jeho fyzického vystupování a těmito diskusemi, nebot se při tom vyjeví hlavní témata novější debaty o inscenování těla v politice. Tato témata jsou sice navzájem velmi úzce propojena, následně však budou heuristicky oddělena, aby bylo možné získat lepší přehled o složitosti aktuálních diskusí ohledně tělesnosti, jež se v Obamově těle protínají.

7 Kvalitní shrnutí základních tezí tohoto směru nabízí (BUTLER in WIRTH 2002: 301-320).

8 K těmto názorům viz shrnutí (BÖHME 2008: 119-135). 
Těchto pět témat současně pojmenovává různé aspekty, které se v politických znázorněních těla dají rozlišit:

1. tělo, o které se vede boj

2. estetické tělo

3. rétorické tělo

4. autentické tělo

5. sexualizované tělo

Bezpochyby existují i jiné možnosti jak rozlišit aspekty působení inscenovaných těl v politice. Zde navržená témata se mi ale zdají zvláště vhodná pro objasnění ústředních konfliktů kolem Obamova těla. Tradiční společenská kritéria dělení podle race (rasy), gender (pohlaví) a class (společenské třídy), která jsou nadále turbulentní nejen v severoamerické společnosti, se dotýkají všech pěti témat a v neposlední řadě vysvětlují, proč k Obamově politickému vzestupu směřovala na jedné straně enormní očekávání a na straně druhé agresivní resentimenty.

\section{Tělo, o které se vede boj}

Ve volebním boji byl Obama od začátku vnímán jako možný „první černý prezident Spojených státü“. Všichni píšící pozorovatelé primaries (primárek) a potom i vlastní Election Campaign (volebni kampaně) pokaždé zmínili barvu pleti tohoto kandidáta ještě předtím, než se začali zabývat jeho tématy a požadavky. Obama ztělesňoval politickou změnu, personální obnovu washingtonské vládnoucí „kasty“ a partnerský př́istup ke světové politice - ale především zastupoval politický podíl zhruba 45 miliónů občanů USA jiné než bílé barvy pleti na nejvyšším státním postu. Tato vysoce výbušná a elementární součást volebního boje se uplatnila při každém veřejném shromáždění, v každém volebním spotu a mediálním eventu ještě dřív, než kandidát vyslovil nějaký požadavek nebo řekl větu do mikrofonu. Ve většině fází volebního boje měl Obama sklon spíše se vyhýbat tématu etnického konfliktu uvnitř americké společnosti (s několika nápadnými výjimkami, jakou byl jeho projev na Selma Voting Rights March Commemoration 4. března 2008). I tak ho však na všech cestách a vystoupeních provázela otázka politického průlomu „černé Ameriky“ - a to naprosto nevyhnutelně kvůli prézentnosti jeho těla.

Obama tedy neměl na vybranou, nebylo možné ho nevnímat jako „černého“ nebo „barevného“ kandidáta. Stěží se dá zobecnit, co právě tato skutečnost znamenala pro jeho veřejné působení. Zdá se, že v Evropě mu přinesla velké sympatie, ale v určitých částech USA naopak prokazatelně vyvolala protesty. Přinejmenším je nápadné, jak málo sám kandidát sázel na tuto součást svých vystoupení. Jeho demoskopicky podloženým úkolem zjevně bylo získat ve volební kampani na svou stranu skeptické bílé muže venkovského ražení. Proto nedávalo smysl, aby stavěl do popředí svůj etnický původ - zvláště když jej i bez toho signalizovalo (i když difuzně) jeho tělo. 
Nepochybná byla Obamova snaha vyvarovat se, pokud to bude možné, vyvolání polarizace, která ve společnosti s přetrvávajícími etnickými konflikty hrozila kvůli vnímání jeho barvy pleti. Jeho stálé ujištování, že chce být po volbách „prezidentem všech Američanů“, je sice tradiční rétorický obrat v historii amerického volebního boje, ale v Obamově případě získal - navzdory případnému předvádění bipartisanship (dvoustrannickosti) - na zvláštní naléhavosti a dost často měl povahu zaklínadla.

Tak Obamovo veřejné vystupování během volebního boje ukazovalo matoucím způsobem obojí: na jedné straně nárok Američanů jiné než bílé barvy pleti plnohodnotně se podílet na politické moci, na druhé straně úzkostlivou obavu, že by tento nárok nemuselo bílé obyvatelstvo i nadále uznávat. ${ }^{9}$ Tato obava měla reálný základ v tom, že Obamův volební tým byl např́ič celou zemí opakovaně konfrontován s rasisticky motivovanou záští vưči jejich kandidátovi. O protagonistovo tělo se rozhořel zápas, který se jenom díky Obamově strategické zdrženlivosti podařilo převést do klidných a nakonec i úspěšných vod.

To vše jsou zvláštnosti amerického volebního boje, které se nedají přenést na veřejnost s jinou strukturou; ale při vší specifičnosti společenských a kulturních konfliktů v pozadí jde přece jen také o relevanci politiky těla, kterou lze pozorovat ve všech moderních mediálních společnostech. Tělo politika je už samo poselstvím a programem a je úplně jedno, nakolik si je toho samotný aktér vědom. Helmut Kohl představoval svým objemným a současně těžkopádným tělem konzervativní politiku „dál takhle“ (i když jeho působení ve funkci kancléře mělo ve zpětném pohledu také inovativní aspekty). Přitom to bylo v neposlední řadě jeho masivní tělo, z nějž mohl vycházet jak uklidňující pocit jistoty, tak i ochromující dojem neměnnosti. I k tomuto tělu si člověk mohl vytvořit zcela rozdílná, ba dokonce protikladná stanoviska, ale nikdo neměl na vybranou, jak se postaví k otázce pohybu nebo neměnnosti, průlomu nebo vyčkávání. V politické inscenační kultuře tedy existují těla, která naprosto nevyhnutelně vynášejí na povrch určité politické zápasy a sporná témata. Vzpomeňme si na útlou, éterickou Petru Kellyovou, která svou defenzivní a současně vytrvalou tělesnou prézentností vnesla v 80. letech do nejvyšších spolkových institucí otázku možnosti pacifistických postojů. Jiný tehdejší politik Zelených, Otto Schily, dokázal konzervativně tradičním zjevem svého těla neustále oblečeného do obleku a kravaty, že si nová ekologická strana získala i konzervativní voličské vrstvy. Jeho tělesný obraz nastolil spornou otázku (mezitím už dávno rozhodnutou), zda jsou parlamentarismus a demokracie zdola (Basisdemokratie) slučitelné.

Dá se usuzovat, že politický konflikt v mediální demokracii je vždy také boj o tělo a jeho význam. S těly jsou spojeny nároky a požadavky, ale především sporné otázky, které se pouhým objevením těchto těl na veřejnosti - téměř nezávisle na momentálních aktérech - dostávají na pořad dne. K faktorům úspěchu kampaně Baracka Obamy patřilo i to, že si byl prezidentský kandidát tohoto tělesného rozměru své politické práce vždy vědom a počítal s očekávatelnými reakcemi na svou tělesnou prézentnost. Jemu

9 Velmi diskutovanou teorii politického podílu, která podtrhuje význam viditelnosti na scénách společnosti, nabízí (RANCIÉRE 2002). 
i jeho mediálním poradcům bylo jasné, že v jeho vystoupeních během volebního boje nemohlo zpravidla jít o to, aby se stylizoval do pózy bojovníka za práva občanů jiné než bílé barvy pleti. Tento rozměr jeho politiky byl tak jako tak nesen médiem jeho vlastního těla. Spíše bylo potřeba tvořivě performativně zachytit možné negativní reakce a resentimenty, aby mohl získat ještě výraznější většinu bílých voličů.

\section{Estetické tělo}

Pozoruhodný rozsah, v jakém byl v mediálních diskursech podroben Obamův vzhled také estetickému hodnocení, nemůžeme rovněž pochopit bez zřetele k jeho barvě pleti. Je totiž sporné, jestli by bílého politika Obamova charismatu zobrazovala média i jako fyzický, tělesný objekt stejnou měrou jako jej. Stalo se sice zvykem, že vnější vzhled politika nebo političky je v médiích podroben důkladnému zkoumání, ale velkým zájmem veřejnosti si mohou být jistí právě tehdy, když se jejich zjev liší od většiny politických protagonistů obzvláštní elegancí nebo mimořádnými prohřešky proti obvyklému stylu. Tento druh pozornosti by se ale neměl zaměňovat s estetickým hodnocením. Soudy o vkusu politiků se zpravidla omezují na zběžné komentáře ke zvláštnostem v řečnickém stylu, ve volbě oblečení, v gestických nebo mimických kompetencích. V Obamově případě funguje mediální zpracování jinak. Už během volebních předkol vznikaly podrobné rozbory toho, jak se kandidát pohybuje a tváří a odkud se vzal zvláštní půvab, kterým se vyznačují jeho performance. Teprve tehdy, když dosáhnou psané i mluvené komentáře o politikově vzhledu takové intenzity, diferencovanosti a reflexivity, jako tomu bylo hned od začátku u Obamy, zdá se být př́ílastek „estetický“ legitimní a smysluplný.

Estetické diskurzy mají od dob klasické moderny už jen málo společného s otázkou, co je „krásné“ a proč pocitujeme smyslový vjem jako „př́ijemný“. V období avantgard, jejichž výtvory byly občas označovány jako „už ne krásná umění“, se orientace filozofické estetiky proměnila. Spíš než o takzvané „umělecké krásno“ šlo nadále spíš o obecnější otázku, jak vjemy - v uměních, ale nejen tam, - působí na pozorovatele a jak jej dokáží podnítit $\mathrm{k}$ tomu, aby vnímal své vlastni vnímání. Touto cestou se estetická teorie rozvinula v komplexní reflexi vlastního vnímání. Zkoumání krásy bylo nahrazeno promýšlením toho, proč nás určité smyslové vjemy dovedou iritovat a vzbuzovat náš zájem. ${ }^{10}$ Právě taková reflexe se od prvních, velmi sledovaných mediálních vystoupení zaměřuje na tělo Baracka Obamy. Komentátoři se rychle shodli na tom, že je Obama pohledný, přitažlivý politik. Tímto zjištěním však debata o jeho zevněǰšku neskončila, ale ve skutečnosti teprve začala. Začali přemýšlet nad tím, v čem spočívá zvláštní sexappeal prezidentského kandidáta, zda vychází spî́ z jeho fyziognomie nebo z rytmu jeho pohybů, a jaký charakteristický rys jeho gest způsobuje, že jsou jeho vystoupení tak přesvědčivá. O estetickém těle tedy v případě Obamy lze mluvit proto, že vnímání jeho těla opakovaně zavdávalo podnět ke zdlouhavým, rozporuplným a zčásti i sebereflexivním 
vyjádřením. Do značné míry pozitivní podtón, kterým se tato vyjádření vyznačovala, zdaleka nelze považovat za samozřejmý. Nebot’ od upozornění Waltera Benjamina na „estetizaci politiky“ během fašismu jsou estetizující zobrazení politiků zatížena obecnou nedůvěrou (BENJAMIN 1997: 42-44). Když mají politická vystoupení silný estetický náboj, je nasnadě podezření z manipulace. Pak rychle vyvstává obava, že zobrazení nablýskaného zjevu má odvést pozornost od temné, negativní, nebo dokonce nebezpečné stránky politického obsahu. ${ }^{11}$ Možná je součástí úspěchu Obamovy koncepce skutečnost, že od samého počátku dovedl taková podezření rozptýlit. Navzdory své schopnosti nadchnout v krátkém čase masy se nikdy ani nepřiblížil k tomu, aby získal pověst demagogického svůdce. Jeho obdivuhodné umění zůstat věrohodný uprostřed opulentních a neskrývaných propagandistických mediálních inscenací plyne z disonantní konstelace: obsahově a argumentačně sledují Obamovy projevy naprosto jasně ideály osvícenského racionalismu. I v nejbouřlivějších fázích volebního boje kandidát spoléhal na projevy, které skoro akademickým způsobem oslavovaly sílu lepšího argumentu (srovnej např. jeho projev-přednášku „A More Perfect Union“ ve Filadelfii 18. 3. 2008). Tento základní rys racionalismu můžeme sledovat na exemplárním příkladu Obamova programového manifestu The Audacity of Hope (2006): místo aby vyzdvihoval sílu politických postulátů, upadá tento spis opakovaně do spíše vědeckého argumentačního stylu. Problémy pojmenovává s důrazem na věcnost, aby pak - jako v nějaké metastudii - na základě stanovených kritérií zvažoval a porovnával různé strategie řešení. ${ }^{12}$ Tento styl by mohl působit suchopárně, kdyby se v napínavé disonanci nepřekrýval s výtečným inscenováním Obamových vystoupení. Racionalita a patos se ve vnímání publika spojují ve vyvážený, harmonický celek.

Také z estetických hledisek je Obamova tělesná prezentace na jedné straně příkladem obecných tendencí naší politické kultury, na druhé straně je ale podepřena výjimečnou strategií, jak dosáhnout úspěchu. Jeho zevnějšek je paradigmatický, protože vyhrocuje estetickou pozornost, které se dnes (třeba v menší míře) dostává mnoha politikům. Neobyčejné ale je, jak Obama zprostředkovává estetizaci i věrohodnost současně, aniž by vyvolal výtky kvůli manipulaci. Našel pro to přesvědčivý koncept: formální eleganci a vnější atraktivitu svého vystupování kombinuje na obsahové úrovni s věcným a občas téměř racionalistickým argumentačním stylem.

\section{Rétorické tělo}

Už během volebního boje, a ještě více po svém nástupu do funkce se Barack Obama projevil jako politik, jehož sebepojetí, publicita i působení jsou do značné míry založeny na politické rétorice. V zahraniční i vnitřní politice bodoval Obama svými zásadními projevy, které - vzpomeňme na jeho proslov k islámskému světu v Káhiře 4. 6. 2009

11 Z toho plyne často velmi skeptické posuzování politické teatrality politology; viz např. (MEYER 2001: 139-174).

12 Německé vydání vyšlo v roce 2008 (OBAMA 2008). 
- vyvolávaly dojem velké vůle po změně a dalekosáhlých reformních snah. Po tělesné stránce inscenuje Obama své proslovy jednoduše a se stylovou jistotou. Stojí velmi vzpřímeně, téměř vůbec se nedívá dolů a dalekosáhle rezignuje na okrasná gesta. Srovnatelně úsporně užívá rukou. Přitom je nápadné, že pravičku a levičku používá rovnoměrně, skoro stejně často. Většinu zdůrazňujících gest vede Obama jak pravou, tak i levou rukou a má sklon obě strany střídat, což navozuje dojem vyváženosti a stability. Pro zvlášt důležité důrazy využívá obě ruce paralelně. Ruce se skoro nikdy nedostanou do blízkosti obličeje; nechává je ve výšce břicha nebo prsou, aby nezmenšovaly působení pohledu a mimiky. Těžištěm Obamova rétorického gesta jsou nepochybně pohyby hlavy a obličeje. Jeho prudké otáčení hlavou během projevu vyzařuje energii a rozhodnost. K pohybovému repertoáru Obamových proslovů patří i zvedání hlavy, při němž vystrkuje bradu jako proti větru - jde o bojovný výraz, který se hodí k tomu, aby rozptýlil pochybnosti o proveditelnosti jeho plánů.

Nádech obzvláštní serióznosti získávají Obamovy projevy tím, že svůj tělesný výraz použivá přísně funkčně. Ǩečník se pohybuje přiměřeně a úsporně, nerozhazuje rukama a nepoužívá velkých gest tam, kde by neodpovídaly dưležitosti řečeného. Obama nikdy př́lišs nevztahuje ruce $\mathrm{k}$ posluchači. Pokud zvedne ukazováček, mírí jím spíše k vertikále než k publiku. Ani o prioritě vyřčeného slova nemůže být pochybností: vlastní důraz vychází stále z Obamova hlasu; ukazovací gesta pouze zesilují akcenty připravené hlasem. Typické je vypichování důležitých slov palcem a ukazováčkem pravé a/nebo levé ruky. Přitom na sebe pokládá palec a ukazováček tak, že se ruka zároveň zdá být volně sevréena $\mathrm{v}$ pěst. Jedno a totéž gesto tak tímto způsobem může zároveň vyjádřit odhodlanost i preciznost. Obama si zř́ídka dovolí nenucené uvolnění svého řečnického postoje nebo neplánovanou gestickou reakci na impulzy publika. Také $\mathrm{v}$ této zdrženlivosti zřejmě počítá s tím, že zapůsobí jeho sympatické vyzařování, které může střízlivostí a pádností performance jen získat. Z kombinace zářivé nenucenosti jeho osobního vystupování s jistou strohostí naučených gest vzniká celkový dojem důvěryhodné serióznosti slibující úspěch.

Ukazuje se, že právě tento efekt serióznosti je v mezičase, ve druhém roce jeho prezidentství, v latentním ohrožení. Obamova rétorika do určité míry ztratila na působnosti, a sice ne řečníkovou vinou, ale vlivem celkového politického vývoje: některé sliby, které zazněly v proslovech, nemohl Obama za dobu strávenou v úřadě splnit. Tento nesoulad mezi očekáváním a skutečností sice není v politice nic neobvyklého a veřejnost $\mathrm{s}$ ním zpravidla také počítá a promíjí jej, ale i tak platí, že publikum, které muselo projít takovou zkušeností, už neprojevuje řečníkovi stejnou důvěru jako před jeho nástupem do úřadu. Ztráta přesvědčivosti se může stupňovat už tím, že se jeho proslovy a slovní spojení nevyhnutelně opakují. Prezident dosahuje ve Spojených státech časté televizní prézentnosti, protože se vysílají všechny jeho veřejné projevy a tiskové konference. Přitom může rychle vzniknout dojem, že se hlava státu blýská spíše svými projevy než činy. Proti tomuto efektu opotřebování je účinný jenom př́sně dodržovaný poměr mezi účelem a prostředkem, který má Obama beztoho na paměti. Jasnost, naléhavost a přesnost výrazu může působit ve prospěch kandidáta už ve fázi seznamování, ale ještě důležitější jsou tyto kvality, když je řečník v nebezpečí, že bude posuzován především podle svých činů (a už ne podle slibů). 
Dají se z Obamovy rétoriky odvodit obecné rady politickým řečníkům? Úsporností gest doprovázejících jeho projevy odpovídá Obama dlouhodobému trendu, který se dá sotva označit za výhradně jeho zvláštnost. Spíše je to obecný obrat stylu politické inscenační kultury podmíněný televizí. Stačí krátký poslech zvukových nahrávek projevů z 20. let minulého století nebo z desetiletí po 2. světové válce a ujistíme se, že rétorický styl dřívějších dob dovoloval větší bombastičnost, než je podle dnešních měřítek vhodné. Mezi televizně protřelými politiky se rozkřiklo, jaké výhody má redukovaná, ale jasná gestikulace. Není tedy zapotřebí Obamova př́íladu k tomu, aby své pohyby během projevo̊ k publiku drželi na uzdě. (Učit se mohou spíš z mimořádné vyváženosti jeho postoje. Je pozoruhodné, jak se řečníku Obamovi daří obracet se ze své řečnické pozice stejným dílem doprava i doleva, a přitom se neodchýlit od stabilní středové linie.)

\section{Autentické tělo}

Teatrologické výzkumy posledních let zdůraznily, že se inscenování a autenticita nevylučují, ale navzájem se podmiňují. ${ }^{13}$ Etymologicky se pojem „autenticita“ odvozuje od pojmu autorství (řecké auto-entes = sebezavršující) a tento pojem opravdu výstižně přenáší různé konotace, které kolem něj oscilují, když se dnes v politických diskurzech mluví o autenticitě. ${ }^{14}$ Autenticita se nesmí zaměňovat s upřímností nebo otevřeností. O autenticitě nějakého vystoupení navíc rozhoduje to, zda může být jeho aktér skutečně pokládán za autora toho, co říká a jak jedná. Ačkoli byl napřríklad Gerhard Schröder širokou veřejností vnímán jako rafinovaný sebeinscenátor, mohl být ve svých vystoupeních současně pokládán za „autentického“. Tento dojem se odvíjel od toho, že se stále zdál být pánem svých inscenací. Schröder zachovával ironický odstup, ukazoval nad očekávání svého publika, že je v obraze, a působil tak, jako by ho bavilo nacházet pro svá veřejná vystoupení zábavnou formu. V každém případě se vědělo, že se dostal do popředí díky svému působení na publikum, ale dokud se mu dalo věřit, že má tyto inscenace (sám) pod kontrolou, nemělo to na jeho autenticitu vliv. Mezitím se ve velké míře začal uznávat význam médií pro moderní demokracie. Z tohoto důvodu se schopnost politiků obratně zacházet s médii nevytýká jako něco negativního, ale pocit̉uje se spíše jako blahodárná.

Stejné vysvětlení, pokud jde o politickou sebeprezentaci, se dá použít i ve vztahu k Obamovi. Samozřejmě jsou si všichni vědomi té „show“, která obklopuje jeho veřejná vystoupení. Nikoho, kdo pozorně sleduje volební boj ve Spojených státech, by nenapadlo podceňovat inscenační charakter Obamových akcí. Už jako prezidentského kandidáta neměli Obamu rádi kvůli tomu, že by ho býval mohl někdo pokládat za přímého a upř́imného. Fungovalo to spíše obráceně: inscenovanost jeho vystoupení lidé vnímali, ale oceňovali právě preciznost a nenucenost jeho inscenací. Dnes může být způsobilost politiků skutečně posuzována podle kvality jejich sebeprezentací: někdo,

13 Srov. např. (FISCHER-LICHTE 2007).

14 K etymologii viz (KALISCH in FISCHER LICHTE 2007: 31-44, zvláště 32). 
kdo se umí dobře inscenovat, nemůže být podle běžného mínění neobratný politik. Aby performance dosáhla takového hodnocení, musí působit elegantně a nenásilně. Je potřeba se vystříhat každého náznaku přehánění nebo křeče. Musíme nabýt dojmu, že si politik stojí nejen za obsahem, ale také formou svých veřejných vystoupení. K autenticitě politika může přispět i dobrá narace v pozadí: Obamovo oficiálně šířené biografické vyprávění o letech, kdy byl mluvčím lidu v Chicagu, jeho vybroušené projevy, když byl poslancem kongresu, a v neposlední řadě jeho velké vystoupení při kandidátském turné Johna Kerryho v předchozích volbách (Boston, 27. 7. 2004). Takové předchozí zkušenosti vedou k závěru, že dotyčný ovládá všechny finesy politické sebeprezentace.

Původ pojmu autenticita ve slovním spojení, které se dá přeložit jako „z vlastní ruky“, poukazuje na to, že na vyvolání dojmu autentičnosti se tělo podílí podstatnou měrou. Zdá se, že autenticita vychází z těla: jde o dalekosáhlý soulad mezi naší představou o tom, jak chceme působit, a tělem. Např́iklad autentický dojem síly vůle a odvahy dokáže řečník vytvořit jen tehdy, když tyto vlastnosti pozorovatel nachází také v jeho těle a pohybech. Autenticita vznikne tam, kde pozorovatel dojde k přesvědčení, že zvláštní atmosféra nějaké situace nebo vystoupení opravdu vychází z aktérova těla. Př́močarost a odhodlání, které byly Obamovi připisovány v průběhu volebního boje, působily autenticky v neposlední řadě proto, že o obou těchto vlastnostech Obamovo tělo svědčilo. Jeho vysokému, vzpř́ímenému a dynamickému tělu byla okamžitě přisouzena odhodlanost, kterou obsahovaly jeho projevy. Zdálo se být jasné, že v kandidátově těle je zakotvena schopnost prosadit se. Tato souvislost se dala najít i v jiných aspektech Obamovy kampaně: mladistvě a sportovně působící tělo dokonale odpovídalo jejímu základnímu motivu - mladému muži, přinášejícímu do Washingtonu svěží notu. Soulad a homogenita inscenace se opět potvrdily jako rozhodující kritéria autentičnosti.

\section{Sexualizované tělo}

Téma sexuality a politiky má ve vztahu $\mathrm{k}$ americkému prezidentskému úřadu dlouhou tradici, k jejímž novějším ohniskům patří široce diskutované mimomanželské aféry Johna $\mathrm{F}$. Kennedyho a Billa Clintona. Způsob veřejného zpracování těchto afér vedl u Clintona k mediálnímu diskurzu o prezidentových konkrétních sexuálních praktikách. Epizoda s Lewinskou byla speciálním př́ípadem, který musíme chápat z hlediska zvláštní politické konstelace, ale z jejího zpravodajského pokrytí vysvítá, jak dalekosáhlé právo na soukromí prezidenta si americká veřejnost i v sexuální rovině nárokuje. Jestliže si pozornost veřejnosti vyžaduje zveřejnění prezidentových sexuálních prohřeškủ, může to vést $\mathrm{k}$ masivnímu oslabení jeho postavení. Nároky veřejnosti na informace se rozšiřují i na podrobnosti o tělesném stavu, což se obecně ukazuje na tom, že američtí prezidenti musí v pravidelných intervalech zveřejňovat lékařské zprávy. Samozřejmě je vážné onemocnění prezidenta politickým problémem, o kterém chce veřejnost vědět. Ale obsáhle se probírají i menší zdravotní poruchy (v Clintonově př́ípadě třeba zbytnění kožní tkáně). Potud má vztah veřejnosti k osobě prezidenta biopolitickou složku: jen zdravý a sexuálně bezúhonný prezident je pokládán za silného prezidenta. Jednak se za 
tím skrývá opravdová obava z narušení praktického vykonávání úřadu, jednak i zjevná asociace (když ne přímo identifikace) národa s tělem prezidenta. V morálce a zdraví prezidenta se má odrážet morálka a zdraví celé společnosti.

Na tomto pozadí je pro Obamu výhodné, že nejsou známé žádné jeho zdravotní problémy ani sexuální eskapády. Obama vypadá, že je v dobré kondici, a právě proto se nemusí nechávat fotografovat při rekreačním běhu tak často jako jeho předchůdci. Stejně jako dlouhá řada jeho předchůdců v úřadě je Obama inscenován jako rodinný typ. Množství autorizovaných snímků ho ukazuje jako součást heterosexuálního páru a hlavu spořádané rodiny. Tradiční rodinný model se zřejmě zdůrazňuje zvlášt kvůli těm konzervativním segmentům bílého obyvatelstva, které přijmou afroamerického prezidenta snáze, když bude odpovídat tradiční představě o heterosexuálním manželství a rodině. Ale i ty skupiny obyvatel, které se budou s tímto obrazem identifikovat obtížně, mohou do Obamy projektovat své představy. Nebot i když reprezentuje tradiční životní styl, zastupuje již jen svým tělesným zjevem tu část amerických občanů, která byla ještě v minulých desetiletích konfrontována s resentimenty a dlouhou dobu nepoznala skutečnou rovnoprávnost. Afroameričané jsou v nejvyšších státních úřadech a na vlivných politických postech stále ještě v menšině. Obama tedy představuje okrajovou politickou skupinu i většinový model heterosexuálního manželství a rodiny současně. $\mathrm{V}$ tom by mohl být další klíč $\mathrm{k}$ jeho úspěchu u publika. V Obamově tělesné performanci se protínají konzervativní rodinné hodnoty a liberální emancipační záměry. Tato kombinace má co nabídnout jak tradicionalistickému, tak i levicově liberálnímu prostředí.

Také z evropského odstupu se dá tělo Baracka Obamy v jeho veřejné podobě sexualizovat. Zde se může stát nosným exotický moment: politici jiné než bílé barvy pleti jsou v Evropě daleko neobvyklejší než v USA. Tato jinakost pro něj vyznívá v evropském vnímání spolu s jeho inscenací jako heterosexuálního otce rodiny příznivě. Spojení sexuální spolehlivosti a blízkosti rodině s očividnou exotičností má nepopiratelně potenciál okouzlit. Avšak i když odhlédneme od působení etnického prvku, ztělesňuje Obama jasně konturovaný mužský model, který je v politické oblasti velmi málo zastoupený: citlivost se pojí s dominancí a rozhodností, racionální uvažování je vyrovnáváno velkou otevřeností vůči novým způsobům jednání a kreativním řešením. Tyto vlastnosti mají svou osobní a erotickou stránku, ale současně se odrážejí v Obamově politickém programu.

\section{Závěrečná úvaha}

Posuzování různých dimenzí Obamovy tělesné sebeprezentace vyvolává na závěr otázku, do jaké míry jsou politické inscenace určovány tělesnými vlastnostmi svých aktérů. Stěží se dá jednoznačně odpovědět, nebot̉ indicie nejsou jednoznačné. Na jedné straně se prokázala velká důležitost fyzického těla v současném inscenování politiky. Ačkoli se dnes dá zobrazení těla v každém ohledu mediálně manipulovat a „dopracovávat“, není možné při vytváření vhodných strategií tělesné sebeprezentace fyziognomii politika prostě ignorovat. Významná část televizního obrazu, který o daném politikovi cirkuluje, 
je založena na veřejných shromážděních. Proto závisí působivost televizních přenosů politika vždycky také na tom, zda se mu podaří zaujmout živě přítomné publikum. V prŕmém kontaktu s publikem při živém vystoupení je ale politik o to víc odkázán na své tělesné zdroje. Dojem, kterým zapůsobí na fyzicky př́tomné publikum, se v každém př́padě dá mediálně zmanipulovat jenom omezeně. Důkazem toho, jak velkou roli hraje fyzické tělo v politice, je také poznatek, že se z tělesné sebeprezentace jiného člověka dá odvodit jen málo tipů a podnětů pro vlastní performanci. $V$ každém př́ípadě bychom neradili žádnému politikovi, aby se - co se týče inscenační techniky - pokoušel Obamu kopírovat. Sebeprezentace je zjevně tak silně závislá na individuálním těle a jeho diskurzivním zasazení, že se musí strategické rady vždy orientovat na konkrétní př́pad..$^{15}$

Na druhé straně by se důležitost těla v performanci neměla přeceňovat. Ještě nikdy nebyly možnosti technické transformace těla tak výrazné jako nyní. Povědomí o metodách médií, která dokáží dodat tělům úplně změněné vlastnosti a působení, zaměřilo naši pozornost na nestálost prezentování těla. Touto prchavostí se vyznačují nejen producenti obrazů, ale i jejich recipienti: co se dnes na tělech cení a obdivuje, se může už zítra stát překážkou mediálně působivé sebeprezentace. Obama by nakonec mohl být i př́kladem toho, jak rychle se může změnit postoj k určitému stylu politického prezentování těla. Už pevným začleněním do tradovaných politických rituálů (tiskové konference, přijetí, fototermíny), kterým se žádný špičkový politik nevyhne, vznikne efekt opakování, který i tělo s největším šarmem postaví do tlumenějšího, střízlivějšího světla. Čím déle je aktér přítomen na politické scéně, tím viditelněji na něm spočívá břemeno toho, že sliby, vycházející z jeho těla, musí být také někdy splněny.

\section{Poznámka k překladu termínů}

Pokud je to možné, jsou pro překlad německých termínů zvoleny již existující české varianty. Pojem „Präsenz“ tak překládáme jaké „prézentnost“ - ve shodě s českou verzí Estetiky performativity E. Fischer-Lichte (FISCHER-LICHTE 2011). Odvozené adjektivum „Präsent“ je tedy analogicky překládáno jako „prézentní“.

Klíčový pojem „(Selbst)Darstellung“ překládáme zejména jako „(sebe)prezentace“, ale podle kontextu také jako „znázornění“. Pro často synonymně užívaný výraz „(körperliches) Erscheinen“ užíváme také ekvivalenty „prezentace“, „zjev“, nebo výjimečně „zevnějš̌ek“, pokud se lépe hodí do daného kontextu.

Pro „tělo“ využívá autor převážně pojmu „Körper“, pokud volí termín „Leib“, je uveden v závorce. „Körperlichkeit“ překládáme jako „tělesnost“.

Sousloví „politische Inszenierung“ je přeloženo jako „inscenování/inscenace politiky“, aby nedošlo k záměně se zažitým českým pojmem „politické inscenace“, vyhrazeným divadelním produkcím.

15 Nepřípustným paušálním soudem by například bylo upřednostňovat v mediální soutěži jen tělo všeobecně pokládané za atraktivní. I z tělesných, hlasových a inscenačních nedostatků mohou politici občas vytlouct kapitál, protože právě nedokonalosti usnadňují ztotožnění a dovedou vyvolat sympatie. 
V případě, že daný německý pojem nemá zažitý český ekvivalent a může hrozit nepřesnost výkladu, uvádíme v závorce německý originál.

Používá-li autor anglické termíny, uvádíme jejich český překlad rovněž v závorkách.

\section{Bibliografie}

BARKHAUS, Annette a Anne FLEIG. 2002. Körperdimensionen oder unmögliche Rede vom Unverfügbaren. In Grenzverläufe. Der Körper als Schnitt-Stelle. München: Fink, 2002.

BENJAMIN, Walter. 1997. Das Kunstwerk im Zeitalter seiner technischen Reproduzierbarkeit. Frankfurt/M.: Suhrkamp, 1997.

BÖHME, Gernot. 2008. Leib: die Natur, die wir selbst sind. In Ethik leiblicher Existenz. Frankfurt am Main: Suhrkamp, 2008.

BUTLER, Judith. 2002. Performative Akte und Geschlechterkonstitution. Phänomenologie und feministische Theorie [USA 1988]. In WIRTH, Uwe. Performanz. Zwischen Sprachphilosophie und Kulturwissenschaften. Frankfurt am Main: Suhrkamp, 2002.

FISCHER-LICHTE, Erika. 2007. Inszenierung von Authentizität. Tübingen und Basel: A. Francke, 2007.

FISCHER-LICHTE, Erika. 2011. Estetika performativity. Mníšek pod Brdy: Na konári, 2011.

FOUCAULT, Michel. 1977. Der Wille zum Wissen. Sexualität und Wahrheit 1. Frankfurt/M.: Suhrkamp, 1997.

HITZLER, Ronald. 2002. Inszenierung und Repräsentation. Bemerkungen zur Politikdarstellung in der Gegenwart. In SOEFFNER, Hans-Georg a Dirk TÄNZLER. Figurative Politik. Zur Performanz der Macht in der modernen Gesellschaft. Opladen: Leske + Budrich, 2002.

KANTOROWICZ, Ernst. 1992. Die zwei Körper des Königs. Eine Studie zur politischen Theologie des Mittelalters. Stuttgart: Klett-Cotta, 1992.

KÜPPER, Joachim a Christoph, MENKE. 2003. Dimensionen ästhetischer Erfahrung. Frankfurt/M.: Suhrkamp, 2003.

MEYER, Thomas. 2001. Mediokratie. Die Kolonisierung der Politik durch das Mediensystem. Frankfurt/M.: Suhrkamp, 2001.

OBAMA, Barack. 2008. Hoffnung wagen. Gedanken zur Rückbesinnung auf den American Dream. München: Riemann, 2008.

RANCIÉRE, Jacques. 2002. Das Unvernehmen. Politik und Philosophie. Frankfurt/M.: Suhrkamp, 2002.

WEIBLER, Jürgen. 2010. Barack Obama und die Macht der Worte. Wiesbaden: VS Verlag, 2010. 
